\begin{tabular}{ll|l} 
Case Reports in & \multicolumn{2}{c}{ Case Rep Gastroenterol 2017;11:446-451 } \\
\cline { 2 - 3 } Gastroenterology & $\begin{array}{l}\text { DOI: 10.1159/000479310 } 2017 \text { The Author(s) } \\
\text { Published online: August 8, } 2017\end{array}$ \\
\cline { 2 - 3 } & $\begin{array}{l}\text { Published by S. Karger AG, Basel } \\
\text { www.karger.com/crg }\end{array}$ \\
\cline { 2 - 3 } & $\begin{array}{l}\text { This article is licensed under the Creative Commons Attribution-NonCommercial } 4.0 \\
\text { International License (CC BY-NC) (http://www.karger.com/Services/OpenAccessLicense). } \\
\text { Usage and distribution for commercial purposes requires written permission. }\end{array}$
\end{tabular}

\title{
Typhoid Fever and Acute Appendicitis: A Rare Association Not Yet Fully Formed
}

\author{
Daniel J. Sartori ${ }^{a} \quad K^{2}$ atherine Sun ${ }^{b} \quad$ Mary Ann Hopkins ${ }^{c} \quad$ Mark F. Sloane $^{a}$ \\ ${ }^{a}$ Department of Medicine, NYU School of Medicine, NYU Langone Medical Center, New \\ York, NY, USA; ${ }^{b}$ Department of Pathology, NYU School of Medicine, NYU Langone \\ Medical Center, New York, NY, USA; ${ }^{c}$ Department of Surgery, NYU School of Medicine, \\ NYU Langone Medical Center, New York, NY, USA
}

\section{Keywords}

Typhoid $\cdot$ Salmonella $\cdot$ Appendicitis

\begin{abstract}
Infections caused by foodborne enteric pathogens including typhoidal and non-typhoidal Salmonella species can mimic symptoms of acute appendicitis. The association between such bacterial pathogens and pathology-proven acute appendicitis has been described, but this link is poorly understood. Here we describe a case of a young man with typhoid fever presenting with histology-proven acute appendicitis requiring urgent appendectomy, and provide a brief review of relevant literature to prompt more widespread recognition of this rare cause of a common surgical emergency.

(C) 2017 The Author(s)

Published by S. Karger AG, Basel
\end{abstract}

\section{Introduction}

Acute appendicitis is a relatively common cause of acute abdomen, especially in young adults [1]. Management of acute appendicitis is primarily surgical and is indeed one of the most frequently cited indications for urgent abdominal surgery [2]. Despite this, the underlying causes of luminal obstruction and subsequent appendiceal inflammation are poorly understood. Gastroenterologists manage numerous conditions that mimic symptoms of acute 
appendicitis - among them other inflammatory and infectious conditions of the small bowel and colon - and the differentiation between these and a potential surgical emergency is of clear importance.

Foodborne enteric pathogens, including typhoidal and non-typhoidal Salmonella species, have a broad range of infectious sequelae in humans. Through a complex system of virulence, Salmonella species adhere to and invade enterocytes leading to an inflammatory response that causes gastrointestinal symptoms ranging from constipation to diarrhea, and can be complicated by intestinal hemorrhage or perforation [3]. Enteric pathogens have been implicated in the pathogenesis of acute appendicitis, possibly through their role in precipitating hyperplasia of the abundant lymphoid tissue in the appendix, and have alternatively been implicated as mimics of appendicitis [4]. The association specifically between Salmonella infection and acute appendicitis, while described previously, is poorly understood and prior reports have struggled to differentiate "bystander" appendiceal inflammation from a causative etiology. Rare indeed are cases of Salmonella infection with pathologyproven full thickness appendiceal inflammation. Below we describe a case of Salmonella typhi infection presenting with histology-proven acute appendicitis requiring urgent appendectomy, and provide a review of relevant literature to prompt more widespread recognition of this rare cause of a common surgical emergency.

\section{Case Presentation}

A 30-year-old healthy man presented with 1 week of subjective fevers and diarrhea in the setting of travel to India 4 weeks earlier. The patient was feeling well while traveling and on return, until 1 week prior to presentation. At this time he reported several days of constipation followed by loose, non-bloody stools and subjective fevers. On presentation to the Emergency Department he was febrile to $102.6^{\circ} \mathrm{F}$ and tachycardic to $130 / \mathrm{min}$ with focal right lower quadrant abdominal tenderness. Initial laboratory values were remarkable for a white blood cell count of $9,300 / \mu \mathrm{L}$ with neutrophilic predominance and procalcitonin of 27 $\mathrm{ng} / \mathrm{mL}(<0.15 \mathrm{ng} / \mathrm{mL})$. Abdominal CT revealed a moderately thickened appendiceal wall without evidence of perforation, and the patient was taken for laparoscopic appendectomy which revealed a grossly inflamed appendix. There was no free fluid or exudates and the remainder of the small and large bowel appeared normal. There was no intraoperative culture data for review. Pathology demonstrated appendiceal crypt abscesses, lymphoid follicle hyperplasia, and neutrophilic invasion primarily in the mucosa but with some extension to the appendiceal wall, consistent with early acute appendicitis (Fig. 1, Fig. 2, Fig. 3, Fig. 4). Blood cultures, which had not yet produced results preoperatively, eventually grew 4/4 bottles of $S$. typhi and stool cultures grew both $S$. typhi as well as Campylobacter jejuni. A stool PCR pathogen panel recapitulated this culture data and additionally was positive for Giardia lamblia and norovirus.

The patient was treated with a regimen of ceftriaxone, metronidazole, and azithromycin for presumptive typhoid fever as well as Campylobacter and Giardia gastroenteritis. His postoperative course was complicated by protracted tachycardia and high-grade fevers as well as transient leukopenia and hepatocellular transaminitis, all of which gradually resolved over a 5-day period. His bowel movements became less frequent and more formed and his abdominal exam remained benign. He was discharged with a 2-week total course of ceftriaxone infusion and oral metronidazole and has remained well since this time. 


\section{Discussion}

This case adds to a small body of literature recognizing an association between enteric bacterial pathogens Salmonella sp. [4-8] and Campylobacter sp. [6, 7] and acute appendicitis, thus serving as a rare example of a common surgical emergency. While there are ample prior reports of associations between these pathogens and conditions that mimic appendicitis [3, 4], chiefly mesenteric lymphadenopathy, ileocecitis, and even bowel perforation, this is one of relatively few that links infection with pathology-proven acute appendicitis. The largest known study of patients with culture-proven bacterial enteritis presenting with appendicular symptoms suggested that only a small fraction had histologically proven acute appendicitis - roughly 8\% for Salmonella sp. and 4\% for Campylobacter sp. [8]. Further, this case is one of culture-proven typhoid fever with $S$. typhi bacteremia, positive stool cultures, and Campylobacter co-positivity; the prior descriptions of Salmonella-associated appendicitis largely involve non-typhoidal Salmonella species as causative pathogens and there are no known reports of an association between co-positivity and acute appendicitis [9-11]. This case is thus unique both in terms of microbiology as well as pathogenesis.

While it remains unclear whether the pathogenesis presented here involves direct bacterial appendiceal invasion or primary luminal obstruction due to lymphoid proliferation, histology-proven acute appendicitis suggests that this case is not one of simply symptom mimicry and that appendectomy was not misguided. This case emphasizes the need for recognition of this and similar patients' presenting symptoms as cause for surgical management, regardless of known culture data pointing to alternative explanations. While culture data resulted postoperatively here, earlier confirmation of enteric bacterial infection would not, and should not, have changed the decision to proceed with operative management. Gastroenterologists should be cognizant of appendicitis and its related complications as real sequelae of complicated enteritis caused by typhoidal Salmonella and Campylobacter species. It remains unknown whether such cases of appendicitis associated with Salmonella or Campylobacter species exhibit more responsiveness to antibiotic therapy, have different rates of perforation or other complications, or follow more aggressive clinical courses. Astute recognition of similar cases will be crucial to better elucidate the natural history of this rare clinical entity.

\section{Statement of Ethics}

Informed consent was obtained for this case report.

\section{Disclosure Statement}

There are no financial disclosures to report.

\section{Author Contributions}

D.J.S. wrote the manuscript and is the article guarantor. K.S., M.A.H., and M.F.S. edited the manuscript and the images therein. 


\section{Case Reports in \\ Gastroenterology}

\begin{tabular}{l|l}
\hline Case Rep Gastroenterol 2017;11:446-451 \\
\hline DOI: 10.1159/000479310 & $\begin{array}{l}\text { @ 2017 The Author(s). Published by S. Karger AG, Basel } \\
\text { www.karger.com/crg }\end{array}$ \\
\hline
\end{tabular}

Sartori et al.: Typhoid Fever and Acute Appendicitis: A Rare Association Not Yet Fully Formed

\section{References}

1 Bhangu A, Soreide K, et al: Acute appendicitis: modern understanding of pathogenesis, diagnosis, and management. Lancet 2015;386:1278-1287.

2 Addiss DG, Shaffer N, Fowler BS, Tauxe RV: The epidemiology of appendicitis and appendectomy in the United States. Am J Epidemiol 1990;132:910-925.

-3 Parry CM, Hien TT, Dougan G, White N, Farrar JJ: Typhoid fever. N Engl J Med 2002;347:1770-1782.

-4 Garcia-Corbeira P, Ramos JM, et al: Six cases in which mesenteric lymphadenitis due to non-typhi Salmonella caused an appendicitis-like syndrome. Clin Infect Dis 1995;21:231-232.

5 Stewart-Parker EP, Atta M, Doddi S: A curious cause of appendicitis. BMJ Case Rep 2016;2016:bcr2016216150.

6 Wright DM, Parry B: Campylobacter and acute appendicitis? ANZ J Surg 2008;78:1142.

-7 Van-Spreeuwel JP, Lindeman J, Bax R, et al: Campylobacter-associated appendicitis: prevalence and clinicopathologic features. Pathol Annu 1987;1:55-65.

-8 Van Noyen R, Selderlaghs R, Bekaert J, Wauters G, Vandpitte J: Causative role of Yersinia and other enteric pathogens in the appendicular syndrome. Eur J Clin Microbiol Infect Dis 1991;10:735-741.

-9 Kazlow PG, Freed J, et al: Salmonella typhimurium appendicitis. J Pediatr Gastroenterol Nutr 1991;13:101-103.

10 Dadswell JV: Acute appendicitis and Salmonella infections. Br Med J 1973;1:740.

-11 Thompson RG, Harper IA: Acute appendicitis and Salmonella infections. Br Med J 1973;2:300.

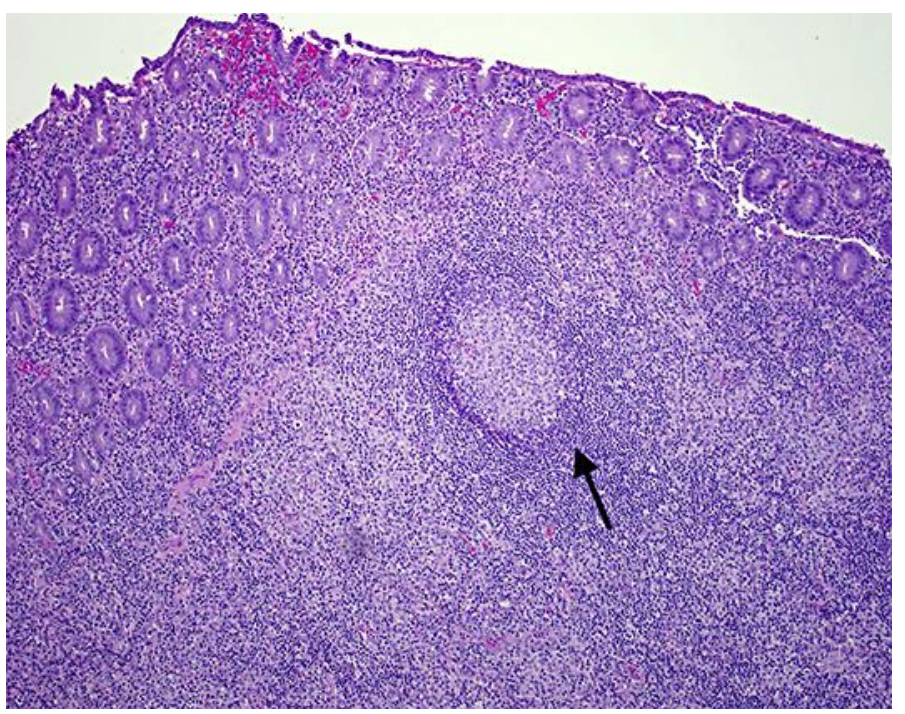

Fig. 1. H\&E staining postlaparoscopic appendectomy demonstrating reactive lymphoid follicle. 


\begin{tabular}{|c|c|c|}
\hline \multirow{2}{*}{$\begin{array}{l}\text { Case Reports in } \\
\text { Gastroenterology }\end{array}$} & \multicolumn{2}{|c|}{ Case Rep Gastroenterol 2017;11:446-451 } \\
\hline & DOI: $10.1159 / 000479310$ & $\begin{array}{l}\text { ( ) } 2017 \text { The Author(s). Published by S. Karger AG, Basel } \\
\text { www.karger.com/crg }\end{array}$ \\
\hline
\end{tabular}

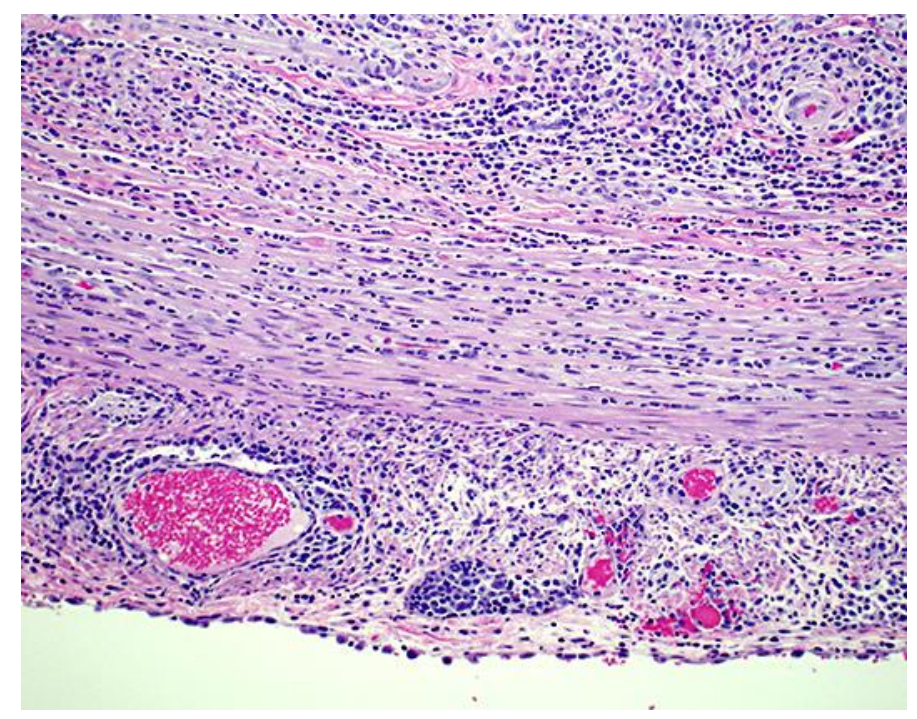

Fig. 2. Mixed inflammatory infiltrate in the appendiceal wall.

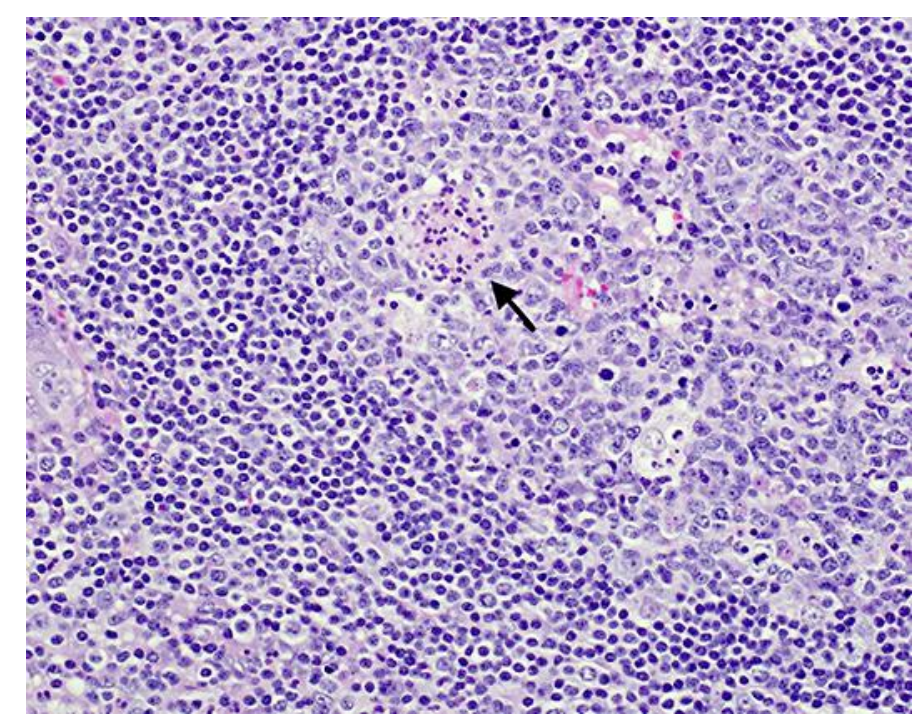

Fig. 3. Germinal center with neutrophil microabscess. 


\begin{tabular}{ll|l} 
Case Reports in & \begin{tabular}{l} 
Case Rep Gastroenterol 2017;11:446-451 \\
\cline { 2 - 3 } Gastroenterology
\end{tabular} & $\begin{array}{l}\text { D } 2017 \text { The Author(s). Published by S. Karger AG, Basel } \\
\text { www.karger.com/crg }\end{array}$ \\
\cline { 2 - 3 } & $\begin{array}{l}\text { Sartori et al.: Typhoid Fever and Acute Appendicitis: A Rare Association Not Yet Fully } \\
\text { Formed }\end{array}$
\end{tabular}

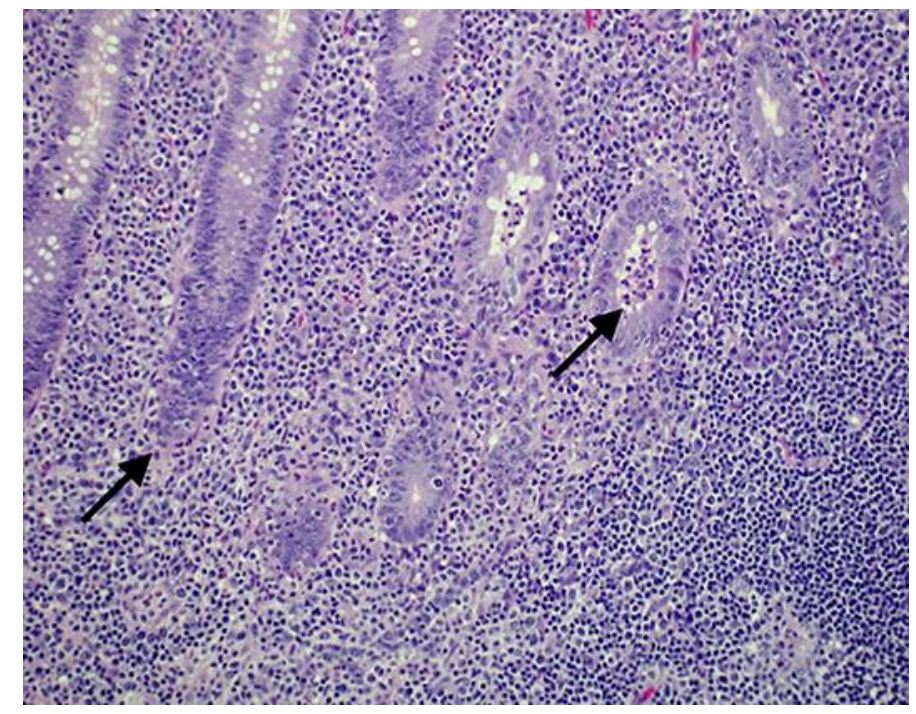

Fig. 4. Cryptitis, crypt abscess, and lamina propria neutrophils. 